\title{
Huawei's Competition Strategy: A Financial Perspective
}

Huawei creates value primarily through its business operations. The primary task of its financial management department is to support and oversee business departments in creating value. Financially, what are the key points that Huawei focuses on as it creates value?

First, Huawei looks at business from an investment perspective and views opportunities strategically. The window of strategic opportunity is usually very short. To seize strategic opportunities, Huawei has the courage to win, is willing to make massive investments, and is skilled at achieving success.

Second, Huawei directs all its efforts towards the same goal and is selective about what it does and what it doesn't do. Focusing on its core business and keeping a sharp focus are the principles that Huawei has always followed in resource allocation. These principles are the key to Huawei's success and also guide Huawei as it allocates financial resources.

Third, Huawei refuses to be opportunistic in the face of big opportunities. The company is not distracted by short-term interests and temptations and does not dwell on sunk costs that may be incurred.

When there are conflicts between opportunities and costs, which is more important? Huawei's answer is opportunities. The company believes that, in the tech industry, the value opportunities bring is higher than their costs. If a strategic opportunity is seized, the company will succeed no matter how much money it spends. However, if it misses a strategic opportunity, it will fail even if it doesn't spend a penny. Being frugal will lead

(C) The Author(s) 2019

W. Huang, Built on Value, https://doi.org/10.1007/978-981-13-7507-1_2 
Huawei nowhere. Therefore, in financial management, Huawei places more emphasis on value creation than on cost savings.

The concept of "Digging In and Widening Out" developed by Li Bing for water management is the key to the longevity of the Dujiangyan Irrigation System in Sichuan Province, China. The wisdom it contains can be applied to far more than just irrigation. Huawei views this concept as a vivid illustration of its business model, and believes that it is also applicable to Huawei if the company wants to survive and thrive in the long run. Huawei's approach is to keep a reasonable profit margin, invest more in the future, and share more value with its customers, suppliers, and partners.

Openness, competition, and collaboration are the basic principles Huawei adopts to enhance its core competencies and build a favorable business ecosystem. An enterprise supply chain is actually a business ecosystem that ties together customers, partners, suppliers, and manufacturers. An enterprise can survive over the long term only when it strengthens cooperation with others, focuses on the interests of its customers and partners, and pursues success for all. Only when Huawei helps its customers create value can it find its position in the value chain.

Economic globalization is the end state of a market economy. This is an unstoppable historical trend. Huawei's development has been a process from going international to going global. In its first 20 years, Huawei was involved in a process of international expansion from China. In its second 20 years and beyond, Huawei operates on a global scale by bringing in talent from around the world and setting up its strategic centers of expertise (COEs) in places rich with strategic resources.

The above key points form the general strategy that guides Huawei's business and financial operations. This chapter elaborates further on these key points.

\subsection{Continuing to Invest Boldly to Seize Strategic Opportunities}

\subsubsection{Seizing Strategic Opportunities Ensures Success While Missing Them Leads to Failure}

We must consider the company's current development from a strategic perspective. Development requires investment, which incurs costs. Hiring new people may impact business results and salary growth. But we must 
look into the future to gain new perspectives. We must seize the right opportunities to develop rapidly. (Ren Zhengfei: Speech at the Mobilization and Training Meeting Regarding Recruitment of New Graduates of 2001, 2000)

The overall goal of our operations is to expand more rapidly. We are facing an unprecedented opportunity. We witnessed a similar opportunity about seven or eight years ago. However, back then we were still small and didn't have the ability to seize it. Now that we're capable of seizing the current opportunity, we must have the courage to win - this is necessary for us to achieve success. (Ren Zhengfei: Eight Points Made After Receiving the "2008 Business Plan and Budget" Report at the EMT ST Meeting on January 31, EMT Meeting Minutes No. [2008] 009)

We are bound to encounter some difficulties because of the lag effect of heavy investments. But this is not a problem as long as we are able to survive. If we could not even survive, no matter how large we are, we still have a problem. (Ren Zhengfei: Working Together Towards the Same Goal, Concentrating Advantageous Resources on Our Core Business, and Having the Courage to Seek Greater Opportunities and Further Widen the GapMinutes of the Work Report on the Wireless Business, Huawei Executive Office Speech No. [2011] 039)

The amount of data traffic may grow faster than we can imagine. As long as there is data traffic, we will have opportunities. Huawei is tasked with transmitting data traffic, and we need to build bigger, wider, and faster data pipes. This is the biggest opportunity we have and it is the core of our business. The platform that we have built over the past 25 years outperforms any of those built by other companies. We can no longer make data pipes wider just by stacking a dozen smaller ones. A bigger platform is now needed for the future. This is a strategic opportunity for us, as smaller companies do not have the capacity to create a big platform. (Ren Zhengfei: Speech and Comments at the Carrier BG's 2013 Strategy Retreat, Huawei Executive Office Speech No. [2014] 016)

When we spot a strategic opportunity, we can pour in huge amounts of resources to bring ourselves up to speed. We must boldly try different methods of investment, not just by adding people. This is different from the way small companies approach innovation. (Ren Zhengfei: Applying the Spirit of the Tortoise to Catch up with the Dragon Spacecraft-Speech at Huawei Annual Management Conference 2013, Huawei Executive Office Speech No. [2013] 255) 
We now need to make heavy, focused investment in our strategic areas. Once we seize the strategic high ground, we can sell our products at higher prices and generate more profits, which can then be invested in advanced research. (Ren Zhengfei: Comments to Staff of the Enterprise BG, Huawei Executive Office Speech No. [2014] 006)

We must be willing to make investments and use modern technologies to develop modern products to seize the strategic high ground. Today, we need to rely on tools to win in the market. In the past, we didn't have money, so we emphasized self-reliance. We did our best to achieve success on our first try, and independently develop testing tools. This is now an outdated approach. We should be willing to invest and use the most advanced tools available to produce the most advanced products. This is the only way for us to increase our share in the market and earn more money. We have to spend money on the tools that we need to secure the strategic high ground. Once we gain control, the valuable resources all around will be ours. We need to be willing to invest and prepare for the future. (Ren Zhengfei: The Best Defense Is a Good Offense-Remarks at a Briefing on the Wireless Network Business, Huawei Executive Office Speech No. [2013] 232)

\subsubsection{Increasing Future-Oriented Investment When the Market Is Experiencing a Cyclical Downturn}

We should have a good understanding of the fluctuations in industry cycles and increase our investment in future opportunities. R\&D doesn't have to be fully aligned with marketing and sales. There should be a twoyear gap between R\&D and marketing and sales. If we don't increase investment now, what will we sow when spring comes, and how will we create new opportunities? We must increase R\&D investment when the market declines so that we can develop when the market recovers. To make that happen, we must be resolute in investing heavily in R\&D. (Ren Zhengfei: Speech at the Work Report of the Product Line Management Office, 2000)

We've recently adopted a strategy of overtaking our competitors on the inside track. This means we should be bold enough to overtake our competitors when global competition is at an inflection point. When we watch a Formula One race, we rarely see racers overtake others on the straight, because this is almost a "mission impossible". Everyone is 
accelerating on the straight. How could you overtake anyone? Our Western peers have decades of experience in management, branding, and building customer trust. If everything goes well for them, and they speed up, they will leave us far behind, making it impossible for us to overtake them. But at a turn, a wrong decision could cause them to fall behind, as people can easily get confused and hesitant at a turn in the road. Nowadays, there is a surplus of electronic products, much like watermelons in autumn. There are just too many of them, so their prices are incredibly low. Nobody knows if the products will ever generate profits again. As long as we maintain our strengths and are bold enough to increase investment at a turn in the road, we are likely to overtake our competitors in some areas. The telecom industry is now at such a turn in the road and is undergoing transformations in technology, networks, business, and business models. (Ren Zhengfei: Seeing the Situation Clearly and Accelerating Organizational Building and Reserve Pool Development to Embrace Huawei's New Development-Speech at a Meeting for HR Directors, 2005)

We are now expanding rapidly in spite of a decline in the overall economy. For a period after the year 2000, we almost collapsed due to challenges both at home and abroad. Logic would have dictated that we should have reduced investments, reshaped our team, and consolidated our markets for future recovery. But we didn't. Instead, we increased investment and grew in the tough environment. When the financial crisis was over, our competitors noticed us. We were still small, but had grown. Following the first round of counter-cyclical growth, we stepped onto the global stage. Now we are experiencing a second round of counter-cyclical growth. I am not sure what we can achieve this time, but at the very least we will have some pricing power. (Ren Zhengfei: Speech at the PSST ${ }^{1}$ Managers' Meeting, 2008)

When the IT bubble burst, transmission products' sky-high prices collapsed. Many leading companies in the industry cut investment in this field. But we didn't, even in the face of extreme financial difficulties. This helped us become the world's second largest company in transmission products. (Ren Zhengfei: Making Youth Shine Out-Speech at the Dedication Conference of the Network Product Line, 2008)

${ }^{1}$ PSST: Products \& Solutions Staff Team. 


\subsubsection{Avoiding Opportunism and Having Strategic Patience in an Era of Big Opportunities}

In an era of big opportunities, we must avoid opportunism and must have strategic patience. (Ren Zhengfei: Avoiding Opportunism in the Era of Big Opportunities - Speech at the Luncheon with the Administrative Team of the Consumer BG, Huawei Executive Office Speech No. [2014] 025)

When a window of big opportunity opens before us, what should we do? I hope you will keep improving yourselves. I'm very pleased to see your tremendous progress within such a short period of time. Recently, I told the Consumer BG that in an era of big opportunities, we must avoid opportunism and must have strategic patience. You should keep up the good work, and work towards our common goals. The more the company earns, the more we will invest in the future. This will help us hone our strategic competitive edge. When we become stronger, we will be able to earn more and attract the best people from all over the world, who will help us hone our edge further, and repeat this cycle. (Ren Zhengfei: Speech at the Japan Research Center's Work Report, Huawei Executive Office Speech No. [2014] 034)

Huawei must have the spirit of a marathon runner and run steadily to sustain profitability. Massive amounts of standardized, digital content are currently being transmitted more easily than before thanks to the Internet. This has driven the real economy to improve after acquiring and digesting information. Information drives the progress of society, the real economy, and services. The Internet is not just about the use of the Internet itself. As long as our smartphones are of high quality and meet the needs of consumers, we can strive to sell them online. We are different from JD and Alibaba in that we can control the quality of our transactions and we have a broad portfolio of intellectual property to protect us in the global market. It is risky to simply be a platform for transactions. You need to understand that cars have to be cars first. The same is true for all things, from finance to tofu. Nothing except Aladdin's magic carpet could ever replace a car. (Ren Zhengfei: Avoiding Opportunism in the Era of Big OpportunitiesSpeech at the Luncheon with the Administrative Team of the Consumer BG, Huawei Executive Office Speech No. [2014] 025)

While we were moving forward slowly like a tortoise, we ignored the flowers everywhere along the road in China. We remained dedicated, up until today. Our Consumer BG has gone through ups and downs with us for many years. It should continue to walk down the right path, with 
enough money to be distributed to employees. We need to identify our own problems and weaknesses, understand who we are, and be ourselves in order to succeed and build our own future. If we can continue to survive 20 years down the road, we will succeed, because many others will have been left behind. (Ren Zhengfei: Avoiding Opportunism in the Era of Big Opportunities - Speech at the Luncheon with the Administrative Team of the Consumer BG, Huawei Executive Office Speech No. [2014] 025)

Some people will say that we are opportunistic. We are actually trying to force you to change in the same way as we did to Consumer BG CEO Richard Yu several years ago - The Consumer BG managed to change after that. At that time, I told Richard, "I believe that in the next two to three years the Consumer BG will greatly improve its product quality, and will continue to do so in the years ahead. You should focus on things like business models and planning management." I also made a suggestion to him, "You must be able to grow watermelons on this peach tree of yours; you can't just grow peaches. One business model is not enough." The tree's trunk is the company's joint support platforms, like service, maintenance, and finance platforms. Its root system needs to be divided among different customers so that the tree can absorb different kinds of nutrients. You need to try different business models. Many companies know the tricks of the trade. As for how to grow watermelons on a peach tree, this is something you'll have to figure out for yourself. (Ren Zhengfei: Heroes Are All Around Us-Speech at the Q4 Regional Presidents' Meeting, Huawei Executive Office Speech No. [2014] 086)

We should not rush into commercializing our new technologies. We must have strategic patience and win as a late mover. We are closely watching the trends in customer demands, and we are not becoming complacent. We are poised to move, like a cat ready to pounce, as soon as market conditions are mature enough. We are not a slow mover that will miss big opportunities when they come. We also need to figure out how to protect customer investments as much as possible. We should not always think about disruption and starting anew every time. (Ren Zhengfei: Remarks at Meetings with the UK R\&D Center, Beijing Research Center, and Financial Risk Control Center in London, Huawei Executive Office Speech No. [2015] 075)

We keep on stressing that strategic patience is key in our consumer business. You must have patience and perseverance. If you rush things, a problem with a single component could cause a malfunction in hundreds of thousands - or even millions - of our phones. This could ruin our 
consumer business, making it very hard to recover. So we have to stay realistic, control our ambitions, and develop at a reasonable pace. Too much excitement is always followed by a mistake. We are in a new age of "Warring States". No matter how fierce the competition becomes, I don't encourage you to engage in destructive price wars. I want you to keep improving quality, and keep running the hard race. That's the right way to ultimate victory. Don't worry if someone else has quickly won a share in a certain market. People switch their phones every two or three years, so just make sure that they buy a Huawei phone next time. That way, in three years' time, we can rise above the waterline and show our true colors. (Ren Zhengfei: Pounding the Streets, We Are the Marathoners Who Always Push for More-Speech at the Consumer BG's Mid-year Conference, Huawei Executive Office Speech No. [2015] 107)

In an era of big opportunities, we must avoid opportunism and must have strategic patience. Advances in basic science are essential to social development. And the development of basic science requires patience and perseverance. Some great people remained dedicated all through their lives despite the fact that they were not recognized. It also took several hundred years before gene technology really took off. Huawei has over 80,000 R\&D employees. Each year, we allocate about $20 \%$ to $30 \%$ of our R\&D spending to research and innovation, and $70 \%$ to product development. We have been investing over $14 \%$ of our annual revenue in R\&D. Over the next few years, our annual R\&D investment will gradually increase to US\$10-20 billion. (Ren Zhengfei: Dedicated to China's Century-old Dream of Revitalizing Science and Technology, Huawei Executive Office Speech No. [2016] 067)

Huawei is forging ahead into the industry's uncharted territory. In this territory, we have no pilot, no rules, and no one to follow. Huawei will gradually slow down its pace as a "follower", and will assume the responsibility of creating guiding theory. We cannot just harvest what others have sown or cultivated. And we should thank Western companies for their piloting over the past 30 years. (Ren Zhengfei: Dedicated to China's Century-old Dream of Revitalizing Science and Technology, Huawei Executive Office Speech No. [2016] 067)

Why have we always stressed that we must focus on our core business? Because we are confident that our assumptions for the window of big opportunity that will open in the future are correct. We must not lose direction or miss the big opportunities because of our greed for small and short-term interests. (Ren Zhengfei: There Will Not Always Be Flowers 
Along the Road Abead-Speech at the HI Huawei Market Conference, Huawei Executive Office Speech No. [2016] 079)

Because of our 28 years of unremitting effort, we have been able to make breakthroughs and become what we are today. And we will be likely to enter uncharted territory for transmission of massive amounts of data. Therefore, we must establish strategic confidence. We believe that we will be able to seize opportunities in this era of big opportunities. We believe that our team can achieve the goal of generating US $\$ 200$ billion in revenue. Of course, we must not be burdened by the US\$150 billion or US $\$ 200$ billion goal. We must not put on our red dancing shoes. We set this goal to guide our transformation in organizational structures, systems, and processes, so as to develop capabilities that will be required in the future. It is not a key performance indicator (KPI). Rather, it is our core competency. Simply stressing this goal is meaningless. (Ren Zhengfei: There Will Not Always Be Flowers Along the Road Ahead-Speech at the HI Huawei Market Conference, Huawei Executive Office Speech No. [2016] 079)

\subsection{Working Together Towards the Same Goal and Deciding What Not to Do in Order to Do SOMETHING GREAT}

\subsubsection{Concentrating High-Quality Resources on Core Business and Strategic Opportunities to Establish and Reinforce Strengths}

We must seize the opportunities presented by industry transformation, have the courage to increase investment, and seize strategic opportunities. With sustainable and profitable growth as the ultimate goal, we need to stay strategically focused and seize the strategic high ground, thus laying the foundation for survival and development over the long term. (Ren Zhengfei: Guidelines on the Analysis of the Business Environment and Key Business Strategies, Corp. Doc. No. [2012] 081)

We must strengthen internal transformation and focus our efforts on building an advantageous position in our core business and strategic markets. We should be cautious about developing in other businesses or markets, as it will compromise our ability to develop our core business and strategic markets. With clear strategic goals, we must focus on vertical business integration and do everything we can to increase efficiency. We can strategically reinforce our long-term strengths only by achieving 
sustainable and profitable growth and higher profitability. If we don't transform or improve our efficiency, we will not be able to seize the opportunities that will pop up over the next several years. (Ren Zhengfei: Speech at the Self-reflection Session of the Executive Committee of the Board of Directors, 2012)

What is a core business? Everything in the world follows a normal distribution curve. The most populous portion of this curve is our core business. We won't go after opportunities on either side of the curve, even if they are highly profitable. There's simply not enough demand. We just focus on our core business and follow major trends. As long as there is data traffic, there is an opportunity for us to succeed. (Ren Zhengfei: Speech and Comments at the Consumer BG's Strategy Retreat in Sanya, 2012)

We must focus on our core business. Value - not technology - must be placed at the center of everything we do. As an auxiliary product line, our Network Energy Product Line needs to show what you contribute to our core business. (Ren Zhengfei: Speech at a Work Report of the Network Energy Product Line, Huawei Executive Office Speech No. [2012] 043)

Sometimes the happier their customers are, the more difficult things are for carriers and equipment providers. But as long as we stay the course in big rivers - that is, our core business - we will eventually reach the ocean. (Ren Zhengfei: Staying Customer-centric and Communicating Huawei at the Strategic Level-Speech at Huawei's Branding Strategy and Communication Retreat on April 12, 2012)

If we cannot survive, there won't be any future! Our value assessment system needs to shift its focus from technology to business success. The Consumer BG is now part of the company's core business, where you must create value. However, value is not just about having leading technology. You still have a very long way to go. You should contribute energy to the core business rather than be a drag on it. If the energy of our core business gets dispersed, it will be very difficult to bring it back together to achieve our goals. (Ren Zhengfei: Avoiding Opportunism in the Era of Big Opportunities - Speech at the Luncheon with the Administrative Team of the Consumer BG, Huawei Executive Office Speech No. [2014] 025)

Huawei has made it clear that we will stick to our needle-tip strategy and be selective about what we do and what we don't do. We have defined the company's strategic roadmap and will follow it through. We will increase investment in massive data traffic and snap up a market share in areas beyond network products. We need to increase our share of data traffic and help customers monetize their data. The size of their networks 
is fixed, but if more traffic flows through their networks than their competitors', this is also a success. We must not waste our strategic resources on non-strategic opportunities. (Ren Zhengfei: Speech at a Meeting with Trainees at the First Training Session for the Global Solutions Elite Team, Huawei Executive Office Speech No. [2014] 064)

We must focus on our core business. Non-strategic areas of business must first be profitable, and we must have the courage to abandon lossbearing projects and seize strategic opportunities. (Ren Zhengfei: Heroes Are All Around Us-Speech at the Q4 Regional Presidents' Meeting, Huawei Executive Office Speech No. [2014] 086)

We need to be like the Yangtze River: Keep to our course and flow forward, while generating massive potential along the way. Every product, large or small, should focus on our core business. New sprouts should also take root and grow in our core business. Don't deviate from this path, or our company will be split into two separate management platforms. (Ren Zhengfei: Innovating to Create Global Value-Speech at the Corporate Strategy Retreat, Huawei Executive Office Speech No. [2015] 006)

\subsubsection{Narrowing Strategic Focus to Become an Industry Leader}

\section{Harnessing major trends successfully to truly lead global trends}

We must not pursue multiple businesses at the same time, or we will become exhausted. Our focus should be on where our key customers are heading. If they change direction, we need to change with them. (Ren Zhengfei: Speech at the Meeting with the Red Managers of Huawei Technologies and Avansys, 2001)

Our investment and HR management policies must be geared towards the most prominent needs of customers and society - essentially the most populous portion of a normal distribution curve. Sure, Huawei stands out in certain domains, but if we want to lead global trends, we need to successfully harness the major trends in our own industry. So for the time being, we will invest in our customers' most prominent needs. This approach will keep us aligned with major trends. (Ren Zhengfei: Still Waters Run Deep-Continuously Improving Ourselves Based on Customer Needs, 2002)

We need to work together towards the same goal. Greater force can only be generated when we focus our efforts on a very small area. Internally, we're good at limiting ourselves to the same source of income, but we're not so good when it comes to working together towards the same goal. 
Our competitors have caught up with us because our R\&D efforts are too spread out. At Huawei, every product line and every engineer is hungry for success, so there are far too many small projects going on here and there. This has weakened us. The Wireless Network Product Line must work together towards the same goal and increase investment in our core business to improve our capabilities and set ourselves apart from our competitors. (Ren Zhengfei: Working Together Towards the Same Goal, Concentrating Advantageous Resources on Our Core Business, and Having the Courage to Seek Greater Opportunities and Further Widen the GapMinutes of the Work Report on the Wireless Business, Huawei Executive Office Speech No. [2011] 039)

We must reduce or remove products that are not profitable from our portfolios. I will not invest in non-strategic products unless the investment is made on a rolling basis and can yield high profits. To make breakthroughs, we need to maintain a sharp focus across the company. A company without focus is like a dull knife: We'll never be able to carve out a piece of strategic markets. (Ren Zhengfei: Speech at a Work Report of the Network Energy Product Line, Huawei Executive Office Speech No. [2012] 043)

To become an industry leader, we must narrow our strategic focus and concentrate all our resources on seizing the strategic high ground in our core business and strategic markets. (Ren Zhengfei: Speech and Comments at the Carrier Network BG's Strategy Retreat in Huizhou, Huawei Executive Office Speech No. [2012] 010)

We must stay ahead of the demand curve. We have no other choice but to stay focused. We should learn from successful US companies. Most of them maintain a laser-like focus, but why? Do they lack the capabilities to engage in other businesses? At the moment, we are not ahead of demand; in fact, we are still trying to catch up. We're at the forefront of the industry, but we can't say with confidence that we are able to set its pace going forward. However, as long as we stay focused, odds are we can make ourselves irreplaceable. (Ren Zhengfei: Our Transformation Goals Are to Harvest More Crops and Increase Soil Fertility-Speech at the 2015 Huawei Market Conference, Huawei Executive Office Speech No. [2015] 016)

For our enterprise business, we should consolidate our position in areas where we have been successful, and further hone our competitive edge vertically before expanding into other areas. Smart cities are emerging. The finance industry is moving its IT to the cloud. Power grids are going digital, and there is an increasing demand from governments and 
enterprises for cloud services. These are all strategic opportunities. Our Safe City solutions are key to establishing our market presence in the smart city domain. But we must not expand too widely; otherwise, we will not be able to focus on strategic opportunities. (Ren Zhengfei: Firm Belief and Strong Focus Lead to Greater Success-Speech at the 2016 Huawei Market Conference, Huawei Executive Office Speech No. [2016] 007)

\section{Developing a clear strategy by boldly letting go of non-strategic areas of business}

Strategy is all about focus, and focus isn't just about what you pay attention to, but what you choose to ignore. This is key to being competitive. There are plenty of opportunities to choose from, but we need to decide what we won't do in order to do something great. When deciding whether to go for an opportunity, we have only one criterion: Whether it can help us constantly improve our core competencies. (Ren Zhengfei: Huawei's Opportunities and Challenges, 2000)

We must have a clear product strategy. We can't do everything ourselves, and we need to have the courage to give up certain things. Only by knowing what to give up can we have a clear strategy. We can consider researching and developing products that have large demand, huge potential for growth, and mature technology. For other products, we can consider joint R\&D. (Ren Zhengfei: Building the Competitiveness of Low-end Access Products with High Quality and Low Costs, 2009)

In order to succeed, we need to learn the art of making strategic tradeoffs. If we find it difficult to succeed in a certain region despite consistent effort, we could reassign our people to places where it's easier for us to succeed. We only need to build a presence in some parts of the world. If we remain stuck in a region that proves to be challenging, we might miss strategic opportunities in other regions. We will make trade-offs while keeping the big picture in mind. The next three to five years may be the best time for us to seize a share of the global market. We must stay focused during this period and seize the strategic high ground of massive data traffic. Once we secure this position, it will be difficult for others to reach our level, and we will have a brighter future. (Ren Zhengfei: Comments to Staff of the Enterprise BG, Huawei Executive Office Speech No. [2014] 006)

In the future, the Internet of Things, smart manufacturing, and big data will generate massive demand for ICT infrastructure. Our responsibility is to provide connections - specifically, equipment that enables connections. The global market is huge, and we won't be able to succeed in every single country. But we'll do what we can, where we can, and it will 
be no small feat. (Source: A Chat in the Garden with Huawei Founder Ren Zhengfei, Huawei Executive Office Speech No. [2015] 098)

In Chinese, the word for strategy can be broken into two parts. The first part is to "take action" or "take to the field". We won't be able to take action or take to the field in the right place at the right time if we lack strategic direction. Interestingly, the second part means to "omit" or let go of something. If you don't give up something, then your strategy won't be complete. We must dare to give up markets with bleak prospects and stay focused. As long as there are profits, that is fine. (Ren Zhengfei: Speech at a Meeting with Employees of the Central Asia \& Cancasia Region, Huawei Executive Office Speech No. [2016] 063)

\section{Resisting easy money utside the confines of core competencies}

Shenzhen has experienced two economic bubbles: one in real estate, and one in the stock market. Huawei didn't get swept up in either. This is not because we're any better than those around us, but because we're serious about technology. When these bubbles swelled up, we certainly had opportunities. But we believe that the future world will be built on knowledge, not on bubbles. So we decided to hold our ground. (Ren Zhengfei: How Long Can Huawei Survive?, 1998)

We cannot allow ourselves to be lured away by the tempting opportunities all around us. With a gloomy outlook for the global economy, we cannot expand everywhere. Doing so will lead to chaos. We must narrow our strategic focus, and ICT infrastructure will always be our area of focus. This will never change. We can only maintain our strategic high ground by giving up non-strategic areas of business. Our Carrier Network BG, Enterprise BG, and Consumer BG must focus on the core business, harness the major trends in their own domains, and establish systematic forces instead of betting on winning in non-strategic areas. Everything in the world follows a normal distribution curve. The most populous portion of this curve is our core business. We concentrate our investment on our strategic direction. To prevent our non-strategic areas of business from developing blindly, we require them to produce a profit margin that is higher than that of our core business. (Ren Zhengfei: Guidelines on the Analysis of the Business Environment and Key Business Strategies, Corp. Doc. No. [2012] 081)

We can only make breakthroughs and move to the forefront of the world in a very narrow domain. We can't allow ourselves to be lured away from our core business. Straying too far into other domains and overdiversification will not help Huawei seize the strategic high ground when 
strategic opportunities emerge. We need to shift our operational focus from the blind pursuit of scale to long-term, sustainable growth - profitability, efficiency, and quality. Product lines and business units in nonstrategic domains need to set high profitability targets. This is to inhibit their expansion and avoid spreading our human resources too thin. We must gradually learn how to seize the strategic high ground in markets, and adopt a top-down approach, where we start with high-end markets and allow that success to radiate down through the mid- to low-end markets. Of course, the precondition is that we have very good products and services. If we cannot offer low-end and mid-range products that are affordable and of high quality, we will be unable to seize the mid- to lowend markets and earn much profit. As these businesses grow, our people must grow even faster. (Ren Zhengfei: Building a Highly Competitive Team-Speech at the Q3 Regional Presidents' Meeting, Huawei Executive Office Speech No. [2013] 093)

While developing high-end technologies for the future, the 2012 Laboratories should dare to forge ahead in our core business. The more difficult the artificial intelligence technology, the harder we should work on its R\&D. We must not make small commodities aimed at earning small amounts of money. We have made a lot of money in the last several years, so we should invest heavily and accelerate our pace of tool development to provide the most advanced tools to our service staff. It takes time for these tools to be ready. We should have strategic patience. (Ren Zhengfei: Speech at a Meeting with Employees of the Noah's Ark Laboratory, Huawei Executive Office Speech No. [2016] 083)

\subsubsection{Maintaining a Narrow Focus to Make Breakthroughs}

Narrowing the scope of focus and making massive investments to achieve key breakthroughs and create positive business cycles

Huawei's policy is one of concentrating resources to the greatest extent possible. By concentrating all of our strengths on a single point, we can achieve major breakthroughs. Why do we need to stick to this approach? Because business success relies on two factors: customer trust and a company's capabilities. AT\&T has what it takes to make personal computers, but an AT\&T branded PC wouldn't appeal to consumers. When we first launched our transmission products, many people might have thought they weren't as good as those produced by the Wuhan Research Institute of Posts and Telecommunications, which was the market leader at the 
time. We had to spend a lot of manpower, resources, money, and time before our products earned the trust of our customers. A company can only do well in a few areas at a time. You can't be great at everything. Focusing on our strengths will help our business grow exponentially. (Ren Zhengfei: Staying Focused to Make Breakthroughs, 1994)

The telecom market is huge, and we can't afford to invest in every single domain. We need to focus all of our resources - manpower, materials, and money - on the strategic areas of business where Huawei is capable of leading the pack, just like our competitors overseas do. All we need is a small inroad, and we can gain market share. Once we have earned money, we will invest more in the market, which in turn will lead to greater breakthroughs and a larger market share. This will form a positive business cycle. If our products continue to take the lead, and we have a large enough market, we can use a cookie-cutter approach to reduce costs. We can replicate our software and reuse it in other products. This approach will increase profit and give us room to thrive. (Ren Zhengfei: Maintaining Technological Leadership to Expand into New Areas, 1996)

As we know, muddy roads can support tanks, but hard floors will shatter when struck with a needle that has enough concentrated force. In other words, if we don't have much money, we should put all we've got into a single point - and I mean everything we've got. This might just help us make breakthroughs. Back in the day, people may have laughed at us for this approach, but focusing all of our resources on a single point is exactly what we have to do. (Ren Zhengfei: Seizing Opportunities, Adjusting Management Systems, and Meeting Challenges, 1997)

When it comes to resource allocation, Huawei has a very sharp focus. We allocate more resources than our major competitors to factors that are critical to our success and to strategic areas of growth. If there is no strategic value, we won't do it. But when we do decide to do something, we go all in - focusing all of our manpower, materials, and money on achieving major breakthroughs. (Source: The Huawei Charter, 1998)

From day one, Huawei bound its mission to the R\&D of core communications network technologies. We invested almost all our profits from re-selling the equipment of other vendors in the research of private branch exchanges. By concentrating all our resources on these products, we managed to make partial breakthroughs, gradually achieved technological leadership, and generated higher profit margins. Our technological leadership created a window of opportunity for increased profit. We then reinvested the profits in the R\&D of the next generation of products. By 
repeating this process, we continuously improve and innovate. Although we have become much stronger now, we still maintain this approach. We concentrate all our resources on core network $\mathrm{R} \& \mathrm{D}$, to develop our core technologies. In this way, Huawei has progressed step by step, steadily growing into a global leader. (Ren Zhengfei: Innovation Is an Inexhaustible Driving Force Behind Huawei's Growth, 2000)

Compared with large companies, small companies are more flexible and responsive to market changes. They can identify new markets and opportunities more rapidly and earn a certain amount of profit before their competitors can react. Large companies are unwieldy and less responsive. But once they enter a market, they can leverage their strengths in platform and scale, concentrate their resources to make breakthroughs, and occupy the market with strong capabilities as a late mover. (Ren Zhengfei: Delegating Authority and Boldly Innovating to Rapidly Respond to Customer Needs, 2001)

We are a company with limited capabilities. We can only catch up with and surpass US companies if we keep our focus narrow. A broad focus would weaken our position, and if we don't keep our focus narrow, we can't generate the force required to make breakthroughs. My guess is that our Strategy \& Development Committee is confident in our profitability over the next few years; they want to invest more in strategic domains. So they want us to give it a try and surpass US companies. We only stand a chance if we narrow our focus down to the size of a needle tip. If our focus expands to the size of a match-head or the end of a stick, there's no way we'll surpass them. (Ren Zhengfei: Applying the Spirit of the Tortoise to Catch up with the Dragon Spacecraft-Speech at Huawei Annual Management Conference 2013, Huawei Executive Office Speech No. [2013] 255)

\section{Focusing all strategic resources on cracking big markets}

We emphasize details too much in our company, and we lack strategists. Our goal is to enter a strategic market. I don't care how much force this takes. We need to break through, secure our presence, and reap the rewards. I am not saying that we should not cut costs or improve quality. But we should also look at strategic opportunities and determine which is more important. We must focus our resources on making breakthroughs in our core business and strategic markets. (Ren Zhengfei: Working Together Towards the Same Goal, Concentrating Advantageous Resources on Our Core Business, and Having the Courage to Seek Greater Opportunities and Further Widen the Gap-Minutes of the Work Report on the Wireless Business, Huawei Executive Office Speech No. [2011] 039) 
I don't think our enterprise business needs to become big and strong within a very short period of time. I think it is more important to be down-to-earth and profitable. The one who outlives others will live best. Huawei is not one of the world's great companies. It became strong because it survived and outlived its competitors. Therefore, I still don't believe it is a good idea to blindly stretch ourselves too thin. Instead, we should focus on a few valued customers and a few competitive products and make breakthroughs in these areas. We don't need to extend our reach to too many areas. Instead, we need to stay focused and make breakthroughs. After we manage to make a breakthrough, it could set an example and generate huge profits when the practice is extended to the entire industry. So we should focus on making breakthroughs in high-value areas rather than shifting our resources to other places as soon as we make some progress. If we divided our resources and allocated them in different directions, this would be a sure path toward ruin. (Ren Zhengfei: Comments to Staff of the Enterprise BG, Huawei Executive Office Speech No. [2014] 006)

\subsubsection{Never Wasting Strategic Resources on Non-strategic Opportunities}

\section{Never wasting strategic resources on minor goals}

In his memoirs about World War II, Lost Victories, German Marshal Erich V. Manstein writes, "The offensive capacity of the German Army was our trump card on the Continent, and to fritter it away on halfmeasures was inadmissible." The strategic principle I learned from this was to never waste strategic resources on non-strategic opportunities. Our company must focus on achieving its strategic goals. We have separated our R\&D from regional operations so that R\&D becomes independent. Bundling R\&D and regional offices together only satisfies low-end customer needs, which means abandoning strategic opportunities. We should channel high-quality resources to valued customers and abandon a certain portion of low-end customer needs. In the future, we will not take the lead in every business domain and may narrow our focus to a single domain. Therefore, if we are not earning a profit in non-strategic areas of business, we should gradually withdraw from them. (Ren Zhengfei: Heroes Are All Around Us-Speech at the Q4 Regional Presidents' Meeting, Huawei Executive Office Speech No. [2014] 086)

We must not waste our strategic resources on non-strategic opportunities. It's fine if a non-strategic area of business is beyond our capacity. We 
simply can't address every single customer need. However, we must gradually open up the interface with our customers, giving our partners room to meet the needs that we can't meet on our own. (Ren Zhengfei: Speech at a Meeting with Trainees at the First Training Session for the Global Solutions Elite Team, Huawei Executive Office Speech No. [2014] 064)

Instead of wasting strategic resources on small market segments, we focus all our strategic resources on cracking big markets. Take our storage business as an example. If we spent a large amount of energy trying to understand all sorts of industries, we would be wasting our strategic resources on non-strategic opportunities. Then we would lack the resources required to make breakthroughs in our areas of focus. Our storage business is currently bleeding money. We need to reduce investment in industries where we can't replicate our experience or expand on a large scale. (Ren Zhengfei: We Can't Fit the Pacific Ocean in a Tea Cup-Speech at a Work Report of the IT Storage Product Line, Huawei Executive Office Speech No. [2014] 045)

We can't focus too much on non-strategic opportunities; otherwise, small interests may weaken our overall strategic strength. The window of strategic opportunity lasts three to five years. Based on how we're doing right now, can we get our foot in the door? There's no point in complaining that our performance appraisal system is cruel. Some people might say, "I think I'm doing fine", but "doing fine" is not enough. We have different expectations for managers at different levels. As managers, you need to think about how to live up to these expectations. If your revenue and profits don't reach the targets, I'm not the one who's going to kick you out. When profits drop, your team's bonuses will shrink. Your team members will earn less under your leadership and will push you aside for sure. (Ren Zhengfei: Why Can't Water from the Himalayas Flow to the Amazon River?-Remarks at the Work Conferences of the Latin America Region, Key Account Departments, and Carrier BG, Huawei Executive Office Speech No. [2014] 044)

We need to continue with our needle-tip strategy. That means focusing our efforts on making breakthroughs that will help us take the lead in the era of massive data traffic. We must not waste too many strategic resources on non-strategic opportunities. (Ren Zhengfei: Our Transformation Goals Are to Harvest More Crops and Increase Soil Fertility-Speech at the 2015 Huawei Market Conference, Huawei Executive Office Speech No. [2015] 016)

Focusing on innovation in our core business is extremely difficult. I've noticed that all of your research and innovation projects are solid additions 
to our core business. This is precisely what we need. Breakthroughs only come with continuous buildup of capabilities and achievements. The massive data flows that we're seeing these days are the first of their kind in history. The systems and equipment that we provide to support these data flows are now among the best around the world. This is a rare honor and it is also a tough responsibility. We will strive to lead the pack in the future. If we fail to do so, we will fall behind and gradually wither away. And all our hard work will have been for nothing. So we must focus on innovation in our core business and must not waste strategic resources on nonstrategic opportunities. It's true that even if we focus our efforts, we may not necessarily succeed. But if we lack focus, we will definitely fail. Technology is advancing so fast that if we hesitate for even a second, we will be brushed aside. (Ren Zhengfei: Remarks at Meetings with the UK RED Center, Beijing Research Center, and Financial Risk Control Center in London, Huawei Executive Office Speech No. [2015] 075)

We don't expect our teams in small countries to make big money, but they must be capable of surviving, turning a profit, and building a strategic buffer zone. To survive, we must put ourselves in our customers' shoes and ensure network quality. We need to figure out customers' pain points about their networks. This requires us to look at data traffic maps, network topologies, satellite maps, economic charts, demographic distribution charts, and other types of charts. We should look at them every month, and see what customers' pain points are and where data traffic is highly concentrated. We will then persuade our carrier customers to invest in these areas to reduce the pressure on their networks and increase their revenue. This will boost their confidence. We cannot hard sell our assumptions to carriers. To avoid ineffective investment, we need to invest mainly in high-value regions, and pass over low-value regions for the time being. We need to have a clear focus in smaller countries. (Ren Zhengfei: Speech at a Briefing by the Tajikistan, Turkey, and Belarus Representative Offices of the Central Asia \& Cancasia Region, Huawei Executive Office Speech No. [2016] 091)

\section{Channeling high-quality resources to valued customers}

We can provide good services to our customers only when we survive. Only when valued customers share more value with us can we become more capable, hire more people, and provide quality services. We have shared interests with our customers. (Ren Zhengfei: Speech at the Awards Ceremony for Small Countries, Huawei Executive Office Speech No. [2013] 039) 
I have been saying recently that we must channel high-quality resources to valued customers. Serving valued customers well is the best we can do for them. Today, I told the executives of a carrier customer in China's Guangdong Province that making money is the foundation for Huawei to survive and thrive. I said the best we could do for valued customers is to channel high-quality resources to serve them and help them achieve greater success. This will create a positive cycle. Our overarching guideline is to serve customers well. The aim of our transformation is to channel high-quality resources to valued customers. For employees working in outstanding teams and on good service platforms, we can give them higher personal grades. We don't need to overemphasize balance across representative offices. If your representative office earns profit, I will assign service staff of higher grades to you to help you better serve customers. In that case, customers will see the value of Huawei and realize that they can succeed only by working with Huawei. As CFOs, you must understand the importance of channeling high-quality resources to valued customers. After making money from valued customers, you should do something for them in return. When I say high-quality resources, I mean we need to raise the personal grades of junior managers in field offices. Their personal grades can be increased again and again. In this way, we will have highquality resources serve our valued customers. (Ren Zhengfei: Comments to Staff of the Guangzhou Representative Office, Huawei Executive Office Speech No. [2013] 057)

We must channel high-quality resources to valued customers. Who are our valued customers? Customers who give us more money. We will assign people with a major-general's capabilities as company commanders to serve our valued customers. This will increase our service cost. Majorgeneral company commanders will definitely provide better service than company commanders at lower levels. (Ren Zhengfei: The Best Defense Is a Good Offense-Remarks at a Briefing on the Wireless Network Business, Huawei Executive Office Speech No. [2013] 232)

We must channel high-quality resources to valued customers and prioritize strategic customers. We need to concentrate our strengths on high-value areas. In the future, Huawei should have the right to choose customers. This doesn't mean that we will place undue pressure on our customers. There are so many customer needs, and it's impossible for us to meet all of them. (Ren Zhengfei: Speech and Comments at the Carrier BG's 2013 Strategy Retreat, Huawei Executive Office Speech No. [2014] 016) 
We must channel more high-quality resources to valued customers and send more capable employees to serve them and improve our service quality. These high-paying employees will erode some of the money we make from our valued customers. These customers will realize that Huawei has not made much money from them and will feel good about that. In addition, we will help them become much more competitive. (Ren Zhengfei: Growing from a Soldier to a General Within Three Years, Huawei Executive Office Speech No. [2014] 031)

We will be a driver of order in the industry, and seize strategic opportunities in the era of massive amounts of data. We will channel high-quality resources to valued customers and work to satisfy their high-value needs by focusing on profits, our core business, and strategic markets. By channeling high-quality resources to valued customers, we are helping these customers seize the market. The market is determined by end customers. If we help our customers seize more of the market and earn more profits, they will buy more products from us and we will succeed as well. (Ren Zhengfei: Comments to Staff of the Brazil Representative Office and Brazil Supply Center, Huawei Executive Office Speech No. [2014] 050)

In the future, our elite teams should focus on designing solutions. As the times change, we must provide carriers with integrated solutions. The price will be a bit higher, but of course the service will also be better. When we say we will channel high-quality resources to valued customers, we do not mean we will only serve valued customers and ignore others. It means that we assign a major general to serve our valued customers, and a lieutenant to serve our regular customers. That is where the difference lies. But we should serve all our customers with the same passion. A major general will certainly perform a little bit better, enabling our valued customers to make more money. In return, we can also make more money. This is what we mean by channeling high-quality resources to valued customers. People and organizations are different, so resources to be invested will also be different. (Ren Zhengfei: Building Advanced Tools and Enhancing Core Competencies to Achieve Success at a Higher Level-Speech at a Carrier BG Briefing on the Service Experience and Phased Acceptance of the "Three Cloud" Platform, Huawei Executive Office Speech No. [2015] 099)

Serving valued customers well is the best we can do for them. We must have the courage to channel high-quality resources to valued customers and further improve our services. We need to optimize our resource allocation strategies and base our resource investment decisions on contracts 
rather than complaints. (Source: Resolution on Improving Services for Valued Customers, EMT Resolution No. [2015] 010)

We need to adjust our presence and channel high-quality resources to our valued customers. We may begin this process with a few select customers in several select countries. In this way, we can build strong ties with one or two strong customers and jointly develop our capabilities. (Ren Zhengfei: Innovating to Create Global Value-Speech at the Corporate Strategy Retreat, Huawei Executive Office Speech No. [2015] 006)

\subsection{Innovating to Create Greater Value for Customers and the Company}

\subsubsection{Placing More Emphasis on Value Creation Than on Cost Savings}

The overall objective of our company is to increase sales and profits. We must increase $\mathrm{R} \& \mathrm{D}$ investment. If the investment turns out to be worthwhile, it will bring us more opportunities, and we must cherish these opportunities. We must also increase investment in marketing and sales, as this can help us obtain new opportunities. We must seize these opportunities, as the value they bring will be higher than their costs. When there are conflicts between opportunities and costs in the company, which is more important? Our answer is opportunities. I always believe that, in the tech industry, the value opportunities bring is higher than their costs. As long as opportunities bring value, an increase in costs is acceptable. (Ren Zhengfei: Minutes of a Work Report on Annual Taxes and Budgets, 2001)

What currently matters the most is whether or not we can seize strategic opportunities; costs are not our primary concern. If we seize a strategic opportunity, we will succeed no matter how much money we spend. However, if we miss a strategic opportunity, we will fail even if we don't spend a penny. Being frugal will lead Huawei nowhere. (Ren Zhengfei: Speech at the Shanghai Research Center, 2007)

When it comes to innovation, we must emphasize value. We must not innovate for the sake of innovation; rather, we must innovate to create value. (Ren Zhengfei: Speech at the Meeting with Staff from the 2012 Laboratories, Huawei Executive Office Speech No. [2012] 035)

Internet companies always talk about disruptive innovation. But Huawei's aim is to create value for the world. We innovate in order to create value. When it comes to innovation, we should focus on the needs of 
society over the next five to ten years. Most of our people should not be looking any further into the future than that. For most of our products, we should focus on sustaining innovation, and we must stick to this approach. At the same time, we will allow a small number of our younger employees to pursue disruptive innovation - exploring whatever seems interesting - within certain boundaries. Such disruptive innovation is open, from which sustaining innovation can absorb energy. When disruptive innovation grows strong enough, it can absorb energy from sustaining innovation. (Ren Zhengfei: Innovating to Create Global Value-Speech at the Corporate Strategy Retreat, Huawei Executive Office Speech No. [2015] 006)

To adapt to changes in future networks, we must innovate continuously. We innovate to help the world move forward and to create value. As we continue to focus on sustaining innovation, we should be more openminded to different ideas and different types of innovation. (Ren Zhengfei: Our Transformation Goals Are to Harvest More Crops and Increase Soil Fertility-Speech at the 2015 Huawei Market Conference, Huawei Executive Office Speech No. [2015] 016)

\subsubsection{Changing the RED Spending Structure and Increasing the Proportion of Investment in Research and Innovation}

Stored program control exchanges are high-tech products that require massive investments. Manufacturers have to keep up with the most advanced technology available and invest heavily in R\&D to make sure their equipment is world-class. On top of this, they need to invest in marketing, sales, training, and services to make sure that their equipment can function well in switching networks, and that it's well suited for quality communications networks. (Ren Zhengfei: Opinions on the Rural Telephone Network and Switch Industry in China, 1994)

We're known for our customer centricity and reliable products. Beyond that, our emphasis on R\&D is the most important factor for us to stand out in the competition with global giants in China's highly competitive telecom market. (Ren Zhengfei: Sticking to Customer Centricity and Keeping up with Global Trends, 1996)

To explore and build our presence in future markets, Huawei earmarks $10 \%$ of its annual sales for R\&D and maintains a tight focus on strategic development. Only by consistently increasing investment can we narrow 
the gap between Huawei and other global players. (Ren Zhengfei: Standing Against Pride and Complacency and Being Mentally Dedicated, 1996)

Every year, the company invests $10 \%$ of its sales in $\mathrm{R} \& \mathrm{D}$ - even more, if necessary. (Source: The Huawei Charter, 1998)

Our research budget accounts for $10 \%$ of our R\&D investment, which is the maximum amount we allow ourselves. It doesn't matter if the money is wasted, but we can't go beyond our budget - and if the budget runs out, that's it. When it comes to investment, it's important to pay attention to normal distribution curves. Investment should be driven by two things: customer needs and technology. We can't rely on just one or the other both are important. (Ren Zhengfei: Corporate Development Should Focus on Meeting the Current Needs of Customers-Speech at a Meeting with Key Employees of the Optical Network Product Line on April 18, 2002)

The money set aside for research must not be used for any other purposes, or mixed with other R\&D budgets. We say over and over again that we're a customer-centric company. If we don't give research its proper due, then the technology-driven side of our business will become very weak. Meeting customer needs is our guiding light. But if we hope to meet these needs, we need the right technology. So we have to guarantee the right amount of investment in technological innovation. (Ren Zhengfei: Comments at the Meeting Regarding the Planning and Budgeting Work for 2005, 2004)

Our overall principle is to continue increasing $\mathrm{R} \& \mathrm{D}$ investment. We just need to ensure a certain degree of profitability. We need to spend a reasonable amount of our short-term profits and increase investment in R\&D to enhance our long-term ability to compete. I recommend that we increase our investment in network R\&D to $12 \%$ of our annual revenue. The R\&D department must use up this investment. (Ren Zhengfei: EMT Meeting Minutes No. [2010] 025)

1. Product development is a well-defined task, and should be subject to disciplined planning, budgeting, and accounting. If R\&D staff make mistakes in product development, they can reapply for budgets.

2. We should change the budget mix for R\&D and increase the percentage of investment in research and innovation. For example, 70\% of our R\&D budgets go to product development and the remaining $30 \%$ to research and innovation. We can consider increasing the percentage of our total R\&D spending to $14 \%$ of our annual revenue. 
3. Research and innovation should be forward-looking, carried out along multiple paths and in multiple waves. Product development should become a task of certainty, following the roadmap defined by the $\mathrm{IPMT}^{2}$ of each product line.

(Ren Zhengfei: Scale New Heights and Forge Ahead into Uncharted Territory Along Multiple Paths in Multiple Waves-Key Messages of Discussions at Mobile World Congress and in Ukraine, Huawei Executive Office Speech No. [2016] 068)

\subsubsection{Ensuring Sufficient Customer-Facing Budgets}

1. Business units must focus on short-term business goals, and more importantly, on the long-term return on investment and business development potential of our customers. They need to prepare reasonable customer-facing budgets based on the baselines set by the company and the actual needs of business development. They must avoid only seeking to reduce the expense rate.

2. Customer-facing and internal operations budgets should be prepared and granted separately. Customer-facing budgets cannot be used for other purposes, and savings in such budgets will not be included in the profits of the current period. Those who use customer-facing budgets for internal operations will be disciplined by the Internal Audit Department.

3. Customer-facing budgets are linked to performance KPIs and managed flexibly. If customer-facing budgets are expected to exceed the quarterly or annual budgets granted, and if the performance KPIs and expense rates are expected to remain acceptable over the coming period (e.g., 6-12 months), the departments whose budgets are to be overrun can apply to borrow the budgets from the subsequent quarters or to increase their annual budgets.

(Source: Resolution on Managing Customer-facing Budgets, Finance Committee Resolution No. [2013] 003)

\footnotetext{
${ }^{2}$ IPMT: Integrated Portfolio Management Team is a cross-functional team that manages the profit, loss, and business success of a product line on behalf of Huawei.
} 
To do business with customers over the long term, we must not reduce customer-facing budgets. Instead, we must ensure that our budgets cover all carrier customers. We need to allocate enough account managers and CC3 roles targeting customer CIOs and CMOs to ensure good sales of our IT products. The headcount of account managers will be set based on need rather than efficiency. How many account managers will be needed for a customer must be clearly managed using checklists, and the number cannot be reduced. (Source: Implementing Corporate Strategy to Ensure Solid Operations of the Carrier Business and Effectively Develop Enterprise and Device Businesses - Speech by Xu Zhijun at a Meeting with Staff from the Southern Pacific Region, SDC Office Speech No. [2014] 008)

Whether or not customers will transform successfully is a very complex issue. It is not something we can help them with, and we should not be in any rush to change how our customers operate. We just need to assign more people to engage with customers. It is understandable if these people do not achieve quick results. (Ren Zhengfei: Speech at the Oath-taking and Awards Ceremony of the Transformation Elite Team, Huawei Executive Office Speech No. [2015] 047)

We must maintain sufficient customer-facing budgets. (Source: Notice on Launching the Annual Corporate Planning and Budgeting for 2017, Corp. Notice No. [2016] 398)

We need to improve the ability of representative offices to deliver a "One Customer, One Solution" experience. We will move our solutions to the field. Representative offices can select products based on the company's product lineup and develop them into solutions. They can also set their own prices based on their actual conditions and long-term business plans. We need to establish elite teams that aim to deliver this "One Customer, One Solution" experience. We should recruit employees who have planning experience, extensive experience in Global Technical Services (GTS), and a strong sense of responsibility from across the company to join in this effort. With extensive experience and a sense of responsibility, these people are an asset to be cherished in the company. We can enroll two or three hundred people to build customized solutions that

\footnotetext{
${ }^{3} \mathrm{Xu}$ Zhijun was the Rotating CEO of Huawei at the time.

${ }^{4}$ SDC: Strategy \& Development Committee was a professional committee under Huawei's Board of Directors. With the authority delegated by the Board of Directors, the SDC set the company's strategic directions and ensured that concerted efforts were made to sustain the company's growth.
} 
meet customers' needs in the current period. These people need to work alongside contract scenario experts. This will allow us to have more indepth operations within a country. Each solution could have two or three people acting as seeds. A local sales team will develop during the course of customization. The seeds can be taken to representative offices around the world, and by doing so, our global sales will become standardized on the basis of customization. (Ren Zhengfei: Speech at a Briefing on the Progress of the ISC+ and CIF Projects, Huawei Executive Office Speech No. [2017] 035)

\subsection{Digging In And Widening Out}

\subsection{1 "Digging In": Ensuring Investments in Improving Cove Competencies and Preparing for the Future}

The concept of "Digging In and Widening Out" was developed by Li Bing and his son over 2000 years ago. Other marvels of the time - such as the Hanging Gardens of Babylon and the Roman aqueducts and bathhouses - have long fallen to ruins, but the Dujiangyan Irrigation System in China's Sichuan Province is still working well and continues to benefit people living in the Chengdu Plain. Why? The concept of "Digging In and Widening Out" is the key to the longevity of the Dujiangyan Irrigation System. The wisdom it contains can be applied to far more than just irrigation. This concept is also applicable to Huawei if we want to survive and thrive in the long run. (Ren Zhengfei: Digging In, Widening Out-Speech at the Commendation Meeting of the Operations and Delivery Division, Huawei Executive Office Speech No. [2009] 009)

"Digging In" means ensuring investments in improving core competencies and preparing for the future, even in times of financial crisis. It also means tapping into internal potential and lowering operating costs to provide higher value services to our customers. "Widening Out" means curbing our greed for profits, avoiding sacrificing long-term interests for short-term interests, and sharing more value with our customers, all while treating our upstream suppliers generously. (Ren Zhengfei: Digging In, Widening Out-Speech at the Commendation Meeting of the Operations and Delivery Division, Huawei Executive Office Speech No. [2009] 009)

Everything we do is for our customers. But ultimately, we are the ones who benefit from doing so. Some people say we treat our customers so generously that they are just taking our money. We must understand the 
meaning of "Digging In and Widening Out". We don't need so much money. We only need enough profits to survive; the rest can be given to our customers, partners, and competitors. This is how we can become bigger and stronger. You must understand the meaning of "Digging In and Widening Out". It relates to guaranteeing everyone's survival. (Ren Zhengfei: Customer Centricity, Increased Platform Investments, and Open Collaboration for Shared Success-Speech at the 2010 PSST Managers' Meeting, Huawei Executive Office Speech No. [2010] 010)

\subsubsection{Constantly Tapping into Internal Potential and Lowering Operating Costs to Provide Higher Value Services to Customers}

To improve the quality of our internal operations and reduce operating costs, we must build a robust management system that includes a series of highly-effective platforms for assessment and incentives and excludes ineffective elements. (Ren Zhengfei: Speech at a Meeting with the Steering Committee on Self-reflection, 2006)

Low prices require low internal operating costs, which should be achieved by optimizing each aspect of operations and reasonably controlling employee compensation. Customers will not pay for the high salary and comfort of our employees. (Source: Huawei's Core Values, 2007)

We must consider internal operating costs no matter what we do. We have to avoid high-cost endeavors that do not create value. (Ren Zhengfei: Speech at a Meeting Regarding General Procurement and Information Security, 2007)

The impact of new technologies on business success will decrease. Low operating costs will be critical to competition, and our future survival and development will rely on management improvement. We must keep our costs low and keep our feet on the ground. We must seize territory first and then take root and blossom. (Source: Minutes of the Discussion on Huawei's Business Strategy for 2009, EMT Meeting Minutes No. [2009] 017)

During current budget assessments, we try to reduce internal operating costs rather than management expenses relating to customers and suppliers. Each department needs to fully understand this. Cutting internal operating costs is conducive to organizational streamlining at HQ and process optimization and simplification. (Ren Zhengfei: Focusing on Strategy and Streamlining Management, Huawei Executive Office Speech No. [2012] 041) 
We must keep our feet on the ground. The earth is our mother, the source of our strength. We must stick to our strategy of high quality and low costs. (Ren Zhengfei: Building the Competitiveness of Low-end Access Products with High Quality and Low Costs, 2009)

In the future, the value of the Internet may not be in helping ICT infrastructure providers and Internet companies make money. Rather, its value will lie in helping companies in the real economy make money by mining and using data. Both ICT infrastructure providers and Internet companies are working to build a better future for the world. Our business model should guarantee sustainable profitability rather than profitability higher than others. We will succeed as long as we can survive. (Ren Zhengfei: Speech and Comments at the Carrier BG's 2013 Strategy Retreat, Huawei Executive Office Speech No. [2014] 016)

\subsubsection{Sharing More Value with Customers and Treating Upstream Suppliers Generously}

We need to pursue a reasonable profit margin. If our prices are too high, competitors will join the game; if our prices are too low, they will destroy the industrial environment and make our own survival impossible. Any product can be unprofitable at first and then become profitable later. We need to use our long-term profitable strategy to support our short-term strategy that is not profitable. The key is to set up a point of marginal cost so that once we exceed that point, we will become profitable. (Ren Zhengfei: Building the Competitiveness of Low-end Access Products with High Quality and Low Costs, 2009)

We are dedicated to the philosophy of "Digging In and Widening Out". We don't want to earn too much money, but we can't afford to lose money for too long. We only need reasonable profits for survival. We will give the rest to our customers and suppliers. We will become the big shot in the industry if we can outlive all of our competitors. Since we are competing with strong competitors, all those who survive are heroes. (Ren Zhengfei: Being a Tolerant and Broad-minded Hero with the Spirit of Openness, Cooperation, and Self-reflection, 2010)

We need to stick to the philosophy of "Digging In and Widening Out", overcoming difficulties on our own and sharing value with others. We need to plant more flowers and less thorny bushes and make more friends and fewer enemies. We must unite as many people as possible to achieve 
shared success rather than becoming the sole winner. (Ren Zhengfei: Over Earth and Ocean, Clouds Roam with Gentle and Swift Motion, 2010)

We must improve our customer services rather than lower prices. Competition on excessively low prices will destroy the entire business ecosystem, which will definitely cost quality in the end. All industries in China are facing this issue right now. We must work hard to improve our profitability, but the extra profit we earn cannot be completely distributed to employees. Part of it must be used to provide high-quality services to our customers. By improving our service quality, we can become more competitive than small companies and reinforce our competitive position. (Ren Zhengfei: Minutes of the Report on the 809 Strategic Guidelines, EMT Meeting Minutes No. [2012] 016)

\subsubsection{Never Pursuing Low Prices, Low Costs, or Low Quality}

My long-term view is that we need to improve the quality of our services from within and avoid significantly lowering prices. If we don't improve the quality of our services, customers will only focus on prices when choosing suppliers. In that case, we will not be able to set ourselves apart from others even if we offer low prices. We need to improve the quality of our products to compete in the market and avoid cornering Western companies through low prices. (Ren Zhengfei: Speech at the EMT ST Meeting, July 2010)

When we select partners for project delivery, quality must be a key factor. As we seek high quality, we also need to pay attention to costs and avoid recklessly pursuing low prices. (Source: EMT Meeting Minutes No. [2010] 022)

We have already established a favorable presence in the device market, and need to develop steadily on the basis of good profitability. In this market, we need to avoid price wars. Previously, we tried to compete on price. We need to stop doing that, or we will destroy order in the marketplace. We need to win customers with high-quality products and services rather than low prices. Price wars will lead Huawei nowhere. (Ren Zhengfei: Comments to Staff of the Guangzhou Representative Office, Huawei Executive Office Speech No. [2013] 057)

In a scarcity economy, a company could earn lots of money by scaling up production capacity to meet demand. But we are now in a surplus economy where supply exceeds demand. In this context, some companies 
compete ferociously on price, and some churn out fake or substandard products. Both of these approaches are shortsighted and short-lived. Some companies squander huge sums of money not on serving customers well, but on forcing out their competitors, aiming to profit handsomely from their customers. At Huawei, one of our core values is to stay customercentric. Our high-quality offerings benefit our carrier customers, so they choose to stay with us. But we will not offer low prices; otherwise, we might have to offer lower pay and in that case, many of our staff might leave our company. Therefore, we must be committed to improving quality because it is essential to our competitiveness. (Ren Zhengfei: Speech at the Q4 Regional Presidents' Meeting, Huawei Executive Office Speech No. [2015] 113)

Even though we are unable to develop a technological edge for some products, we can still standardize and simplify these products so they are maintenance-free. To achieve success, we must also create advantages and set ourselves apart from others in terms of business and management models, as well as the spirit of dedication, capabilities, and sense of responsibility of our employees. We must not follow the path of low prices, low costs, or low quality. If we do so, the strategic advantages we have established over the past 20 years will be destroyed, and we will lose our competitiveness. (Ren Zhengfei: Our Transformation Goals Are to Harvest More Crops and Increase Soil Fertility-Speech at the 2015 Huawei Market Conference, Huawei Executive Office Speech No. [2015] 016)

We must change our focus from low costs to high quality. We must leave our component suppliers a reasonable level of profits and use highquality components to make high-quality products. We must provide customers with high-quality services and a superior experience. High quality may incur higher costs, but it will also create greater value. With highquality products, we will be better positioned to mitigate risks and maintain stable operations in the face of international competition and economic fluctuations. (Source: BOD Executive Committee Meeting Minutes No. [2015] 023)

Do low-end products yield low profit? Not necessarily. Once we get the quantity up and ensure zero maintenance, profit doesn't necessarily have to be low. We cannot force the price down. We don't have to drop our prices just because others drop theirs. That's just driving them into the ground. We have to first show consumers our quality, then we can allow our prices to be a little higher. And every year, some mature hardware and software can filter down from our high-end products to the low-end products. Last 
year's high-end model is this year's low-end device. That way, users who don't have as much money to spend can still enjoy good quality. That's also success for us. So we shouldn't underestimate or simply ignore the low-end phone market. (Ren Zhengfei: Pounding the Streets, We Are the Marathoners Who Always Push for More-Speech at the Consumer BG's Mid-year Conference, Huawei Executive Office Speech No. [2015] 107)

In the future, we must remain absolutely committed to two things. One is intellectual property, and the other is product quality. As soon as we make money, we will reinvest it in improving services. That's what we mean when we talk about the "Van Fleet Load". We have to rapidly build up a global service system. If we can't build it fast enough, then we can train people in China, and send the best service people overseas to develop service capabilities. Once the capabilities overseas are built up, then we can have local service staff provide high-quality services to local customers, and the Chinese staff we assigned there can gradually come back home. We need to constantly innovate our service models, because in mobile phones, the focus of competition is slowly shifting away from R\&D. Once a certain level of usability has been reached, further improvements to these products will no longer deliver much value to consumers. R\&D will start to lose traction. Apple will also struggle to find ways to improve their phones. This is a sign that the technology is getting close to the point of saturation. Once the hare makes it to the saturation point, it has nowhere else to go, and all it can do is wait for the tortoise to catch up with him. This is the time when we have to speed up the rollout of our service network, and prepare to lead the world. (Ren Zhengfei: Consumer BG Services Should Be "Genghis Khan's Horseshoes": The Firm Footing for Our Global Ambitions-Speech at the Consumer BG Services Strategy Report, Huawei Executive Office Speech No. [2016] 012)

\subsection{Openness, Competition, and Collaboration}

\subsubsection{Nothing Can Stop Us If We Remain Open}

A closed culture cannot absorb the strengths of others and will gradually be marginalized. A closed organization will eventually become like stagnant water. We must openly learn from others in every area, such as R\&D, sales, services, supply management, and financial management. We must not cling to what has worked in the past and become self-centered. In our process of innovation, we need to stand on the shoulders of giants and 
absorb as many external strengths as possible in the same way as a sponge absorbs water. We must not pursue independent innovation behind closed doors. With openness, Huawei will be able to survive in the long run. Without openness, it will soon perish. (Ren Zhengfei: Deepening Our Understanding of the Corporate Culture of Staying Customer-centric and Inspiring Dedication, 2008)

An integral part of Huawei's core values is openness and initiative, but our EMT members were divided on this for quite some time when we were determining our core values. Huawei is already a strong innovator. Is openness so important? Due to our past successes, our confidence, pride, and complacency have increased, and we are becoming increasingly selfabsorbed. We need to change. We need to be open and learn more from others. Only by doing this can we set new goals, truly examine ourselves, and develop a sense of urgency. (Ren Zhengfei: Openness, Compromise, and Huidu, 2010)

Why do we emphasize openness? The global market is enormous and ICT infrastructure is as wide as the Pacific. It is so large a market that no single company can dominate. Failure to stay open will lead us into a dead end. So why are some people against openness? They are blinded by their vested interests. We must get rid of vested interests. This is what we have always been doing. We are getting rid of what makes money for us. If we don't do this, others will ultimately replace us. The Stone Age did not end because there were no stones left in the world. We must remain open and stay committed to openness, no matter whether we are weak or strong. When we are open, our advantages will be gone, so we will have to work even harder to gain new ones. (Ren Zhengfei: Speech and Comments at the Carrier Network BG's Strategy Retreat in Huizhou, Huawei Executive Office Speech No. [2012] 010)

We must build an open system rather than a closed one. Lack of openness will only lead to decline. If we do not learn from the Americans, we will never surpass US companies. (Ren Zhengfei: Speech at the Meeting with Staff from the 2012 Laboratories, Huawei Executive Office Speech No. [2012] 035)

Openness is one of the factors that contribute to the success of capitalism. There was no economic success in China when it shut its doors to the outside world. Therefore, we must open up. Currently, many people in China hope to grow stronger behind closed doors. This is a mistake. Throughout history, China has shut itself away from the outside world for long periods of time, making it impossible to become 
strong. The US is the world's most open nation, and thus the world's strongest. Though the US may fall behind from time to time, it has seen constant waves of innovation: Apple, Facebook, and others. As long as the US remains open, who can stop it from moving forward? (Ren Zhengfei: Absorbing the Energy of the Universe over a Cup of Coffee, 2014)

Many companies and research institutes around the world are very good at one particular area of R\&D. But we have the strongest integration capabilities, so we shouldn't be afraid of opening up to the outside world. On average, only one out of every 1000 academic papers has commercial value. People in academia will be happy if we approach them and ask them to tell us about their problems. Our Thought Research Center should be up and running soon. In this center, there will be only one department the Secretariat Office, which is a meeting coordination team responsible for preparing meeting minutes after brainstorming sessions. We must invest in the future, and this is the only way for us to secure a position in this area in three to five years' time. (Ren Zhengfei: Speech at a Meeting with Employees of the Noab's Ark Laboratory, Huawei Executive Office Speech No. [2016] 083)

We should be highly open-minded when it comes to research on artificial intelligence. You are right by conducting research yourselves. Otherwise, you won't be able to know whether you're moving in the right direction, or which research results are valuable. There are companies that are doing better than us. We can incorporate what they have done. The Google system has scanned lots of books from Spain and Latin America, so its translations from English into Spanish are very accurate. We should bring in such machine translation capabilities. In terms of natural language processing, can we partner with the industry's leading companies? We can sponsor them and use the systems they develop. To be a global leader, we must be open-minded and inclusive. (Ren Zhengfei: Speech at a Meeting with Employees of the Noab's Ark Laboratory, Huawei Executive Office Speech No. [2016] 083)

\subsubsection{Competition in the Future Will Be Between Supply Chains}

The price we offer to our suppliers must be high enough for their survival. It is not a good idea to create a vicious market environment, as it makes it impossible for both sides to survive. If we lose our suppliers, we will have 
to find new ones. Doesn't qualifying new suppliers incur extra cost? (Ren Zhengfei: Remarks at a Meeting with Procurement Managers, 2000)

When a company grows to a certain size, it must build strategic partnerships with its suppliers to ensure the ongoing supply of materials and components. This is also necessary for the company to develop rapidly. (Ren Zhengfei: Speech at the Report on Supply Situations, 2000)

Competition in modern times is no longer between individual enterprises; it's between supply chains. An enterprise supply chain is actually a business ecosystem that ties together customers, partners, suppliers, and manufacturers. An enterprise can survive over the long term only when it strengthens cooperation with others, focuses on the interests of its customers and partners, and pursues success for all. (Source: Huawei's Core Values, 2007)

Future competition will be between supply chains. The robustness of the entire supply chain - upstream and downstream - is vital to Huawei's survival. (Ren Zhengfei: Digging In, Widening Out-Speech at the Commendation Meeting of the Operations and Delivery Division, Huawei Executive Office Speech No. [2009] 009)

The value of enterprise management lies in the effective, marketoriented integration of all resources and elements, such as capital, technology, talent, markets, R\&D, manufacturing, and supply chains, to help the company compete successfully in the market. This is also the goal of enterprise management. (Ren Zhengfei: News Release, 2009)

We need to enhance strategic cooperation with high-quality resources in the industry, and we can also form alliances with our peers to jointly create value for the world. As we do this, we also need to protect customer resources.

First, we need to stress joint value creation and contribution, rather than disruption. If we can work with Cisco and make our equipment compatible, it will be a success for us. We should not reject Cisco. In certain domains, we need to establish alliances with Cisco. We can have a look at what path Cisco has chosen and provide necessary support. We need to be more open-minded. We have become what we are today by turning our competitors into allies.

Second, to stay competitive, we need to strengthen strategic cooperation with top industry players. We can buy from any vendor who delivers to our standards. We need to be open-minded. If we don't buy from these vendors, they may sell to our competitors, who, by integrating resources of companies that have no dealings with us, will become as competitive as 
us. This will be bad for our company. Therefore, we need to be open, collaborate with European and US vendors, and share value with them.

(Ren Zhengfei: Speech at the Briefing on Industry Trends and Progress in Fixed Networks, Huawei Executive Office Speech No. [2015] 109)

\subsubsection{Value Sharing Is Vital to a Robust Business Ecosystem}

Only when we help our customers create value can we find our position in the value chain. Only when we truly understand the needs and challenges of our customers and provide them with good services to help them hone their competitive edge, will they grow with us in the long run and agree to long-term partnerships. As a result, we will survive and thrive. So we need to focus on the challenges our customers face and provide them with competitive communications solutions and services. (Source: Huawei's Core Values, 2007)

While working with others, Huawei must not act like a black widow, a kind of spider that eats its mate in order to gain nutrition for its offspring. In our past dealings with partners, Huawei either "ate" or "dumped" our partners after collaborating for one year or two. Now that we have grown strong enough, we should become more open-minded and modest, and look at issues with a deeper insight. We must pursue more effective models of collaboration for shared success. Our R\&D teams are open, but I expect to see even greater openness, both internally and externally. It has not been easy for Huawei to grow into what we are today. As we continue to progress, we need to absorb as many ideas as possible from the outside world and get inspiration from them. Do not be narrow-minded. (Ren Zhengfei: Customer Centricity, Increased Platform Investments, and Open Collaboration for Shared Success-Speech at the 2010 PSST Managers' Meeting, Huawei Executive Office Speech No. [2010] 010)

We are increasingly aware that the purpose of our global business operations is not just to increase sales and profits. More importantly, we need to invest over the long term in countries where we operate, to create jobs, pay taxes, and promote local technological advances. At the same time, we should make the local industry more competitive, help communities prosper, and make due contributions to the development of every country where we have a presence. In this way, we can create a mutually beneficial business ecosystem. The obstacles we face in the business environment today are something we must experience as we grow from a small company to a big one. We must adopt an open mind to face difficulties and 
setbacks ahead of us, think proactively, and act calmly. This is the only way to gradually improve our business environment and ultimately get the industry, government, and society to accept our development. (Ren Zhengfei: Guidelines on the Analysis of the Business Environment and Key Business Strategies, Corp. Doc. No. [2012] 081)

We must learn to share value with our allies and look at the world with an open mind. Through this, we will eventually win over the world. We need to be open. Huawei will soon be number one in the ICT industry. If we only want to dominate the world without sharing any value with our partners, we will ultimately fail. Many people throughout history who wanted to dominate the world perished before their goals were achieved. Those who are unwilling to give up markets are not strategists. I suggest that you watch a movie called From Victory to Victory. Don't be too concerned about the temporary gains and losses of individual projects or markets, because our goal is the global market. (Ren Zhengfei: The Best Defense Is a Good Offense-Remarks at a Briefing on the Wireless Network Business, Huawei Executive Office Speech No. [2013] 232)

Senior managers should read three corporate documents very carefully. The first is Resolution on Improving Services for Valued Customers. For the Consumer BG, we have to do just that - improving the quality of services for our valued customers in every phase of user service, including product quality, sales, and after-sales. The second document is Resolution on Sharing Value with Suppliers. The purpose of this document is to improve our relationship with suppliers, especially with our strategic suppliers. In the past, we supported small companies as our suppliers, and of course it was impossible to ensure high quality. We are producing enormous quantities of products now, so we need to find key suppliers, and build strategic partnerships with them. We need to share value with our suppliers to motivate them to offer us parts of even higher quality, so that we can better serve our consumers. Huawei is firm in its policy of openness: opening up to external partners and promoting open source internally. We don't necessarily have to invest in production lines of other manufacturers or build our own. We just need to sincerely share value with our suppliers and we will then succeed together. (Ren Zhengfei: Pounding the Streets, We Are the Marathoners Who Always Push for More-Speech at the Consumer BG's Mid-year Conference, Huawei Executive Office Speech No. [2015] 107)

The Consumer BG should implement an elite team strategy. We don't want to expand the team too much; otherwise, it will collapse in the end. 
When we implement our Contribute and Share system in the Consumer BG, it's not just for employees or suppliers; we also need to share value with sales channels, retail partners, and other parties involved. The strategy of sharing value widely means we don't need to build a huge organization. We need to correctly assess our own situation. Don't think that we are omnipotent. We need to keep self-reflecting on our weaknesses. This way, we will find the right approach for the Consumer BG to develop. I think that if we are going to hire more people, we should also add new capabilities. We need to focus on details when planning human resources for the Consumer BG. For example, ask yourself a few questions: Where do you need to increase headcount? What standards do new people need to reach? What contributions should they make? You need to prepare a list of such questions first. (Ren Zhengfei: Pounding the Streets, We Are the Marathoners Who Always Push for More-Speech at the Consumer BG's Mid-year Conference, Huawei Executive Office Speech No. [2015] 107)

I hope that our Consumer BG will use the world's best cameras, acoustics, and computing capabilities to create the world's best mobile phones. We don't need to develop all components by ourselves. Instead, we should integrate our research system with the platforms of our strategic suppliers so that we can share value together. Even if we conduct research on most of these components, we should give our partners the opportunity to produce and supply them. We must not do everything on our own. We have shared value with our employees. Why can't we share value with our strategic partners as well? We must not do everything independently, as that will turn us into an international orphan. (Ren Zhengfei: There Will Not Always Be Flowers Along the Road AheadSpeech at the HI Huawei Market Conference, Huawei Executive Office Speech No. [2016] 079)

You need to study the meeting minutes sent to the Capital Construction Management Department - Sharing Our Success Beyond Huawei. We must be open-minded and allow high-quality suppliers to become our partners and grow together with us. The mechanism adopted in the Capital Construction Management Department makes workers feel respected, and this has greatly boosted their initiative and motivated them to deliver high-quality projects at a faster pace. We must share our success with all of our partners. (Ren Zhengfei: Remarks at a Meeting at the National Academy of Sciences of Belarus, Huawei Executive Office Speech No. [2016] 087) 


\subsection{Becoming a Truly Global Company}

\subsubsection{Building a Global Business Ecosystem to Keep Growing}

As the Chinese economy goes global, our country can prosper only by learning the best practices of other countries. In this era, a company can only thrive by having a global strategic outlook and can only keep growing by building a global business ecosystem. Likewise, to have a successful career, employees need to have a global perspective and the ability to work globally. (Ren Zhengfei: Speech at a Farewell to Employees Heading Overseas, 2001)

Currently, many big companies think they are not big enough, and seek to become bigger by constantly acquiring other companies. Why are companies obsessed with mergers and acquisitions? It's because the world of the future will be dominated by big companies, not small ones. US politics in fact serve big companies. The aim of the US's globalization strategy is to help big companies sell their products all over the world. But products can be sold globally only when they are of high quality. Small companies can't benefit much from globalization. Only big companies can make big money through market monopolies. They can reinvest the money they make in new functional domains like $\mathrm{R} \& \mathrm{D}$, marketing, sales, and management, thereby sustaining their profitability. This is well understood the world over, and is leveraged by many players as they ride the wave of globalization. (Ren Zhengfei: Comments to Staff of the Technical Support Department, 2002)

We are facing very good opportunities in the international market. The addressable market in China may shrink in one or two years, but the overseas market is developing rapidly. I've been to some countries, which are just like what China was ten years ago, and have very bright prospects. There are many opportunities out there. We have never faced such promising markets. In the past, we always waited to snap up a small share after others had taken up almost all of the market. Now we are able to enter national markets as they open. Take Russia as an example. It is double the size of China. Just imagine how many optical fibers will be needed there. Isn't this a great opportunity for us? We have to pick up our pace to grow into an international company, and all departments must understand the market issues. (Ren Zhengfei: Speech at a Meeting with Key Employees of the Optical Network Product Line, 2002)

Economic globalization is the end state of a market economy. This is an unstoppable historical trend. Capital seeks out the best places to grow. It 
is like a migrating bird, always seeking out the best niche to settle in. (Ren Zhengfei: The Market Economy Is Best for Competition; Economic Globalization Is Inevitable-Speech at the Commendation Meeting of Finance, Huawei Executive Office Speech No. [2009] 005)

After the original global economic landscape is disrupted, protectionism is inevitable. We must be able to cope with it. With a gloomy outlook for the global economy, we must resolve issues surrounding globalization at the cost of some short-term interests. (Ren Zhengfei: Guidelines on the Analysis of the Business Environment and Key Business Strategies, Corp. Doc. No. [2012] 081)

Globalization demands that ideas, cultures, and nations become more global. Each nation has its unique qualities. For example, Germany and Japan are advanced manufacturing powers; the French are romantic and have a keen sense for color and mathematics. That is why we can locate our fuzzy mathematics research center and color research center in France. (Ren Zhengfei: Speech at the Japan Research Center's Work Report, Huawei Executive Office Speech No. [2014] 034)

\subsubsection{Leveraging Relative Advantages in Global Competition}

For Huawei, globalization does not mean we simply hold ourselves to European and US standards, especially in terms of compensation and cost. If our labor costs run out of control, we could lose our fundamental competitive advantage. Our compensation policy must be designed in a way that ensures we remain profitable globally. (Source: Minutes of the Report on the Globalized HR Management Project, EMT Meeting Minutes No. [2006] 018)

Thanks to the large number of talented individuals in China, we have gained a unique competitive advantage - low R\&D costs. Our business model is to grow our network equipment business, and build world-class platforms for marketing, sales, service, R\&D, and management. Based on these platforms, we are cultivating our managers, developing new businesses, and earning profits through capital investments in these new businesses. (Source: Guidelines on Global Competition Strategies, EMT Resolution No. [2007] 021)

We must develop targeted strategies to help us compete in different locales, product sets, and customer groups. We cannot expand everywhere and adopt a "one-size-fits-all" approach around the world. In addition, we must think strategically in the areas of government relations, customer relations, and competitive and cooperative relations. We must clarify the 
strengths we need to build to set us apart from our competitors and be clearly felt by our customers. (Source: Guidelines on Sales Priorities, EMT Meeting Minutes No. [2008] 014)

The correct path forward is to recognize that there will always be a division of labor, and that we must leverage our relative advantages in the international division of labor. This will help us gradually improve our weaknesses. Complaining won't solve anything. (Ren Zhengfei: The Market Economy Is Best for Competition; Economic Globalization Is InevitableSpeech at the Commendation Meeting of Finance, Huawei Executive Office Speech No. [2009] 005)

\subsubsection{Locating Strategic COEs in Places Rich with Strategic Resources}

I think we should build COEs based on the cultural characteristics of specific regions around the world. If a region has the most talented people in a certain domain, we should build a COE in that region for that particular purpose. For instance, there is a lot of talent in India with very good negotiation and bidding skills, so we should build our COEs for negotiation and bidding in India. (Ren Zhengfei: Speech at the EMT ST Meeting, 2009)

Based on business needs, we should build different COEs in different countries around the world. The building of COEs is a global strategy that addresses global business needs rather than only the needs of a particular country. (Ren Zhengfei: Integrating Project Estimation, Budgeting, Accounting, and Final Accounting to Support Project Operations-Speech at a Briefing on the IFS Project, Huawei Executive Office Speech No. [2010] 007)

COEs must be built on an ongoing basis based on a unified plan. The plan for building global COEs will be developed in line with the company's strategy management process. If the direction of a COE is clear, it can be built immediately. (Source: Requirements for Building Global Centers of Expertise and Recruiting Talent, EMT Meeting Minutes No. [2010] 033)

Our business is going global. While we tap into China's resources and market strengths, we need to rapidly pool together, allocate, and share our global talent, capabilities, experience, and resources around the world. (Source: Requirements for Building Global Centers of Expertise and Recruiting Talent, EMT Meeting Minutes No. [2010] 033)

Why not step up efforts to build different COEs around the world? For example, we can establish a shared services center for auditing in the UK or the Netherlands. When I said we should build COEs, the Human 
Resource Management Department prepared a form, which was completely R\&D-centric. This is still technology-oriented, and they have not shifted their focus to balanced, comprehensive capability improvement. In our Financial Risk Control Center, why not do project risk analysis and control in collaboration with experts from Wall Street? We have many fellows now, some of whom are exceptional young people from outside of China. I think our operations management department, financing department, and audit department can also bring in some talented individuals, but they don't have to be as senior as fellows. When it comes to COE building, we are still technology-oriented and are not fully improving our managerial capabilities. (Ren Zhengfei: Success Is Not a Reliable Guide to Future Development-Speech at the Huawei Market Conference on January 17, 2011, Huawei Executive Office Speech No. [2011] 004)

In its first 20 years, Huawei was involved in a process of international expansion from China. In its second 20 years, Huawei will go global by building COEs that focus on global talent and address global needs. (Ren Zhengfei: Minutes of the Meeting Regarding How to Share Value with Dedicated Employees, Huawei Executive Office Speech No. [2011] 010)

Our R\&D department operates dozens of COEs around the world. These centers are not responsible for local or regional operations (e.g., Europe). They are there to lead Huawei's global business. We will continue our efforts to plan and build global COEs, which will gradually bridge the capability gaps of our specialized teams. (Ren Zhengfei: Comments at a Meeting with Sales Financing Experts, Huawei Executive Office Speech No. [2012] 025)

I said in January that we will establish settlement centers in Japan and Europe focusing on Japanese yen and euro, respectively. We will diversify our financing channels and make some change in our capital settlement efforts. (Ren Zhengfei: Comments at a Meeting with Sales Financing Experts, Huawei Executive Office Speech No. [2012] 025)

The top priority for the Japan Research Center is to increase investment and take bigger steps in development. You do not have to focus only on the applied sciences for materials. You can also delve into the area of quality management. People in Japan take things very seriously. This is their biggest advantage. We can establish testing centers in Japan and Germany, integrate our three testing centers in China, Japan, and Germany, and increase investment in large capacity, high speed, and data security assurance. (Ren Zhengfei: Speech at the Japan Research Center's Work Report, Huawei Executive Office Speech No. [2014] 034) 
We need to adopt a more open approach in our manufacturing. We need to continue to make good use of Japanese lean production consultants and German consultants. We can also directly bring in manufacturing managers, engineers, and technicians from leading companies in developed countries like Japan and Germany to rapidly make Huawei's manufacturing technology and management world-class. (Ren Zhengfei: Speech at the Factory at Songshan Lake, Huawei Executive Office Speech No. [2014] 052)

We need to place our strategic COEs in areas rich with strategic resources. Large companies should boldly channel their resources in a specific direction to shorten the catch-up period and extend the window of opportunity. This is the business version of a Van Fleet Load. (Ren Zhengfei: Remarks at Meetings with the UK Re'D Center, Beijing Research Center, and Financial Risk Control Center in London, Huawei Executive Office Speech No. [2015] 075)

Quality is a top priority for our products, including hardware and software. Of the top software companies in the world, one is in Germany and all the others are in the US. Therefore, we should set up a software research center in Seattle and separate research in physics from that in logic. Without measures like this, we won't be able to produce the best possible software. The US has a robust innovation system, backed by an uncompromising spirit and strong momentum. We must not cling to what has worked in the past. We need to place our strategic COEs in places rich with strategic resources. (Ren Zhengfei: Pounding the Streets, We Are the Marathoners Who Always Push for More-Speech at the Consumer BG's Mid-year Conference, Huawei Executive Office Speech No. [2015] 107)

When we develop high-end devices, we should locate technology development in Japan, put the brain in the US, and carry out hands-on development activities in Suzhou, China. If we want to produce better high-end products, we need to build an ecosystem for the development of high-end devices. What are high-end products? They are products that align well with consumer demand and are apace with the times. One of the very important technologies of the future is going to be image processing, and in Japan there are many specialists in this area, because they have been cultivating people in image processing for decades. Japanese companies working on images are dying, but the DNA is still there. We should set up an image research center in Japan to absorb the Japanese philosophy of "small, light, precise, and compact" and its strengths in image processing. This will give a huge boost to our phones features. We can do the development in 
smaller cities in China. Average pay is relatively low there, so with the same salary, our staff in smaller cities can have a higher standard of living than in Shanghai. (Ren Zhengfei: Pounding the Streets, We Are the Marathoners Who Always Push for More-Speech at the Consumer BG's Mid-year Conference, Huawei Executive Office Speech No. [2015] 107)

We should place our COEs in regions rich with industrial resources. We need a global vision for this: Don't just focus on Beijing, Shanghai, and Shenzhen. We must not just operate in China; we should have a global presence. When I talk about first-tier cities, I don't just mean Beijing and Shanghai; I mean global first-tier cities, including those in the US. Employees can choose the locations where they want to work. Secondtier cities will be our R\&D delivery bases in the future. (Ren Zhengfei: Focusing on the Core Business and Seizing Strategic Opportunities-Speech at the Product Investment Strategy Review Meeting, Huawei Executive Office Speech No. [2015] 123)

We should support technological development in Russia and former Soviet republics (mainly Belarus and the Ukraine), because these countries were very strong in technology. Today, those foundations are still there, and people in these countries are down-to-earth and apply themselves to what they do. They are different from many in China, who are often restless and busy speculating in real estate, stocks, or P2P lending. Few people conduct scientific research in a down-to-earth manner. China is vast, but there isn't a single quiet desk. Down-to-earth people can devote themselves to scientific research in the same way the Japanese aim to win Nobel Prizes. We must support their research - and they will be of great help to us when they manage to accomplish something in the future. (Ren Zhengfei: Remarks at a Meeting at the National Academy of Sciences of Belarus, Huawei Executive Office Speech No. [2016] 087)

Over the years, we have gradually set up our COEs in areas rich with strategic resources. So far, we have established $26 \mathrm{COEs}$ around the world, and this figure is increasing each year. These COEs have gathered together many world-class scientists, who provide guidance to our company across every facet of our business. These COEs themselves are also evolving. The talent pyramid at Huawei used to be a closed system. We have blown open the top of this pyramid to absorb the energy of the universe. We must strengthen our communication and cooperation with scientists from all over the world, sponsor the research of those who move in the same direction as us, get actively involved in international industry and standards organizations, and attend all kinds of academic seminars. We should drink 
more coffee with bright minds to absorb their brilliant ideas and sense the direction of future development. Only long-term, persistent investment will ultimately lead to strategic breakthroughs. As breakthroughs become more complex, cross-field cooperation will become more important than ever. Therefore, we should blur the boundaries between organizations and between specialized fields and prepare the soil for breakthroughs. In addition to developing managers and experts internally, we should also introduce more capable ones from outside of Huawei. Russian scientists are more willing to take on long-term challenging projects, so we can integrate them with our Chinese employees who prefer short-term success. Japanese scientists are attentive to details; French scientists are romantic; Italian scientists are committed to work; and scientists from the UK and Belgium are great world leaders. These are all qualities that are extremely valuable to Huawei. (Ren Zhengfei: Dedicated to China's Century-old Dream of Revitalizing Science and Technology, Huawei Executive Office Speech No. [2016] 067)

We need to search extensively outside Huawei and set up our COEs in places rich with strategic resources. We also need to establish aggregating platforms by geography and by area of expertise. The role of these platforms is to digest ideas. We will invest in universities and sponsor the research of professors. We don't want to own their papers or their patents. We don't want to own anything, and their research projects don't have to be successful. It doesn't matter if they fail, as long as they tell us why and how they have failed. They just need to give us some lectures on their research process and the progress at certain milestones. If the research does not go well, we want them to tell us where and how it has gone wrong. Our aggregating platforms will summarize key takeaways from these scientists. (Ren Zhengfei: Scale New Heights and Forge Abead into Uncharted Territory Along Multiple Paths in Multiple Waves-Key Messages of Discussions at Mobile World Congress and in Ukraine, Huawei Executive Office Speech No. [2016] 068)

\subsubsection{Attracting Global Talent and Building a Global Management Structure}

Stepping up efforts to build a global presence of technology and new business

To future-proof our business, we need to adapt to the requirements for new technologies like mobile Internet, new consumer electronics, ICT, 
and cloud computing. We also need to expand into new business domains, including enterprise business, new energy, and chips for consumer electronics. Therefore, we need to look at this from a global perspective, and step up efforts to plan new technologies and new businesses accordingly. (Source: Requirements for Building Global Centers of Expertise and Recruiting Talent, EMT Meeting Minutes No. [2010] 033)

We will not change the path of our globalization. Huawei's facilities in Europe are European companies and our facilities in Japan are Japanese companies. They are not Chinese companies. We should gradually localize them in terms of mindset. (Ren Zhengfei: Comments at a Meeting with Sales Financing Experts, Huawei Executive Office Speech No. [2012] 025)

When establishing our Strategic Advisory Council, we should first adopt an international approach. The ideas from one region do not represent the entire world. The strategic direction drawn from these ideas may not be correct, and we may pay a price for pursuing it. We should not take a wrong path when the strategic direction is correct, and we also don't want to be the only one who succeeds in this strategic direction. We want to be just part of the correct strategic direction, not the only one. We must share value with others, and incorporate this into our core values. This way, we will have fewer conflicts with other players in the world. (Ren Zhengfei: Speech at the EMT ST Meeting, 2012)

There are two things that I'm very worried about. First, we have not established a good presence around the world. Second, we aren't acquiring enough new technology. If we become self-obsessed and complacent, we may miss the best opportunities. If we do everything on our own, we will soon be cast aside by history. (Ren Zhengfei: We Can't Fit the Pacific Ocean in a Tea Cup-Speech at a Work Report of the IT Storage Product Line, Huawei Executive Office Speech No. [2014] 045)

We need to establish an architecture for a broad quality system. We should set up broad quality COEs in China, Germany, and Japan. Materials science in Japan is extremely advanced. Don't underestimate Kyocera. ${ }^{5}$ Their gallium nitride is a ceramic and the main material used in radio communications. We should use materials in Japan to develop the world's best products. Germany is known for its culture of extreme rigorousness, and its technology and management capabilities are excellent; many Chinese tend to let their minds wander but are good at structural thinking.

\footnotetext{
${ }^{5}$ Kyocera is a Japanese multinational ceramics and electronics manufacturer headquartered in Kyoto, Japan.
} 
Combining the strengths of the three cultures together will support Huawei's broad quality strategy. We can also replace people with tools and methods, produce irreplaceable and unrivalled products using the best tools in the world, and ultimately become a global leader. (Ren Zhengfei: Speech at a Work Report on Corporate Quality, Huawei Executive Office Speech No. [2015] 067)

We can set up a delivery capability research center in Japan, which should not be located in the same places as our two existing research centers in the country. The Japanese are well-known for their attention to detail, so our service team can bring onboard many of them to help us win on the front line. This research center should be able to help us find keys to engineering delivery and quality assurance. Our GTS should also leverage the strengths of local resources around the world. (Ren Zhengfei: Speech at a Briefing on Business Strategies for Professional Services, Huawei Executive Office Speech No. [2016] 062)

Bringing in talent from around the world regardless of their background

We are in the process of aligning ourselves with international standards. In this process, we should not ask non-Chinese people to make compromises to the Chinese. Rather, this is a process in which Chinese people integrate into the world. (Ren Zhengfei: Speech at a Briefing by the Corporate Information Security Department, 2001)

Huawei will step up its pace of internationalization to embrace the trends of economic globalization. We require our employees to spend more time learning and improving themselves. IPD, ${ }^{6}$ ISC, ${ }^{7}$ and financial IT systems are all important steps we take to go international. We will continue to develop our Chinese employees into international talent. At the same time, we will work harder to develop non-Chinese local employees, cultivate a batch of key non-Chinese employees, and place them in our management and decision-making teams at all levels. (Ren Zhengfei: Key Points for Management, 2002)

${ }^{6}$ IPD: Integrated Product Development is a set of models, concepts, and methodologies for managing the full lifecycle of research into innovative technologies and product development.

${ }^{7}$ ISC: Integrated Supply Chain is a system for managing the supply chain. Comprised of manufacturers and suppliers of raw materials and components, it provides products and services to customers through planning, procurement, manufacturing, order fulfillment, and other associated activities. 
To meet the challenges of going international, we need to bring in international and professional talent in different areas, including technical services, supply chain, procurement, strategic cooperation, branding, overseas public relations, human resources, and commercial affairs. We only need to hire a limited number of high-end employees, who will act as seeds to improve our overall capabilities. (Source: EMT Resolution No. [2005] 005)

In sales and services, we will speed up the localization of our staff working outside China. This is a general principle of the company. This principle has been effectively implemented in the service domain, and sales should catch up as soon as possible. The Chinese employees we send to work outside China face a challenge as they try to integrate into local communities. Cross-cultural communication is difficult for them. In addition, the cost of local employees is much lower. Therefore, localization of employees outside China is a goal we will pursue over the long term. (Ren Zhengfei: Strengthening Professionalization and Localization, 2005)

We will hire more high-end professionals with global vision and appoint them as department directors. Our supply chain department should hire a vice president from Japan or Germany. Our audit department should recruit high-end talent from the US. We aim to have non-Chinese members in the Staff Team (ST) of every level-1 department and regional office in 2008. We should be open-minded towards external talent. All employees who follow company policy and contribute more than they cost will be recognized at Huawei, regardless of their country of origin or seniority. At Huawei, employees are evaluated according to policies, not based on their experience. We should get rid of our narrow-minded views of talent. (Source: Guidelines for Delivery, Working Capital Management, and Team Building, EMT Meeting Minutes No. [2008] 013)

We should deploy more non-Chinese managers. We can do this if we have a sound oversight system in place. When we do public relations in India, why not hire Indians to engage with Indians? We can provide advice behind the scenes. Our PR positions should be gradually filled by local employees. At the Shanghai World Expo 2010, I hope we will have many non-Chinese employees to host foreign delegations. This will make them feel better. Of course, there can be a Chinese employee accompanying the delegations. However, we must definitely not have a group of Chinese employees host a group of non-Chinese. We should have visionary and politically savvy people working in public relations. (Ren Zhengfei: Speech at the EMT ST Meeting, 2009) 
We should bring in talent from around the world regardless of their background. As Huawei is going international, we will gradually raise the compensation packages for exceptional employees to international levels. This is the only way for us to attract world-class experts to Huawei. Why is the US such a developed country? It's because the US has a nurturing environment. Talent in the US comes from around the world. At Huawei, most employees are Chinese. Huawei has developed by hiring people from all parts of China, and the next step is to hire people from all over the world. (Ren Zhengfei: Focusing on Business Success and Attracting Global Talent, Huawei Executive Office Speech No. [2014] 026)

A company cannot become great by relying on only one person. It must learn to unleash the potential of outstanding people. In the R\&D process of our product lines, we must develop a large number of maintenance experts and build elite teams. In the future, maintenance may play a more important role than $\mathrm{R} \& \mathrm{D}$. We must create an environment where world-class talent can survive and thrive. In sales and marketing departments, it is very difficult for externally hired managers who are dropped into the middle of a tightly-knit "band of brothers" to succeed, because the "band of brothers" may refuse to follow their orders. However, scientists can survive at Huawei. Their work does not involve so many interpersonal relationships. We will establish elite teams in our sales and marketing departments. Externally hired managers in these departments will be sent to the elite teams for training and practice and form their own "bands of brothers". (Ren Zhengfei: We Can't Fit the Pacific Ocean in a Tea CupSpeech at a Work Report of the IT Storage Product Line, Huawei Executive Office Speech No. [2014] 045)

At our recent management conference, we said we will change and improve our talent pyramid. Why? Japan and Germany are the two countries that are the best at electronic manufacturing. We will improve our manufacturing processes in line with Japanese standards. We will hire Japanese technicians and ask them to build a production line at Huawei. Our Chinese technicians need to be benchmarked against their Japanese counterparts. If they meet Japanese standards, they can receive a salary as high as that of Japanese technicians. Currently, we aim to set the salary of our key marketing, sales, and R\&D staff by referring to US standards, and the salary of our key manufacturing staff by referring to Japanese standards. This will give us a higher standard to look up to in every domain. (Ren Zhengfei: Speech at a Training and Practice Session of LTC Trainers in Germany, Huawei Executive Office Speech No. [2014] 061) 
The US is still the strongest when it comes to software. It has a strong sense of innovation. We need to increase our investment in future outstanding talent in the US, and place the outpost units of our Noah's Ark Laboratory in the US or Canada. Ireland is close to the east coast of the US. Is it possible for us to find great architects in Ireland? The average age of our experts outside of China is 40 to 50 , so we should begin to bring onboard young seeds. These seeds do not have to be all Chinese. They can be non-Chinese $\mathrm{PhD}$ holders. They will be in the prime of their life a decade later and play a pivotal role at Huawei. If we don't bring them onboard now, we will soon be short of successors in our experts' team. There are also many outstanding people in Hong Kong and Taiwan who have returned from studying in other countries. However, there aren't any big industries in these two regions, so we can attract more of them to the company. These days, there is a lot of hype around artificial intelligence, and some bubbles might burst soon. We should source talent as soon as possible. When the river floods, we can catch fish in the street. (Ren Zhengfei: Speech at a Meeting with Employees of the Noab's Ark Laboratory, Huawei Executive Office Speech No. [2016] 083)

\section{Building a global management structure}

The company must go international. Finance has already gone international, and we need to do the same for Supply Chain and GTS - and quickly. We have no other choice. (Ren Zhengfei: Employees Will Never Become Generals If They Don't Know Where They've Gone Wrong, Huawei Executive Office Speech No. [2007] 033)

We must have a global view when establishing our HR presence. We should select several countries with a nurturing legal environment and a good price-performance ratio in employee compensation, and assess the feasibility of making them our low-end R\&D bases or other business bases. We need to make a comparative analysis of policies and environments in advance. (Ren Zhengfei: Minutes of a Briefing by HR, 2007)

Our business structure in India can refer to our model in the US. We can consider bringing in independent directors who are influential in society. In addition to that, we need to streamline our business and governance structures to meet our market expansion needs in India. (Source: Minutes of the Report on the Proposal for the Business and Organizational Structures in the US, EMT Meeting Minutes No. [2010] 007)

We need to go global at a faster pace and establish a global management structure. We need to develop and promote a large batch of managers around the world who have a strong sense of mission, strategic thinking, 
business acumen, and strong motivation, and place them in our management teams at all levels. We need to create mechanisms that encourage healthy competition between managers. (Ren Zhengfei: Guidelines on the Analysis of the Business Environment and Key Business Strategies, Corp. Doc. No. [2012] 081)

Open Access This chapter is licensed under the terms of the Creative Commons Attribution-NonCommercial-NoDerivatives 4.0 International License (http:// creativecommons.org/licenses/by-nc-nd/4.0/), which permits any noncommercial use, sharing, distribution and reproduction in any medium or format, as long as you give appropriate credit to the original author(s) and the source, provide a link to the Creative Commons licence and indicate if you modified the licensed material. You do not have permission under this license to share adapted material derived from this chapter or parts of it.

The images or other third party material in this chapter are included in the chapter's Creative Commons licence, unless indicated otherwise in a credit line to the material. If material is not included in the chapter's Creative Commons licence and your intended use is not permitted by statutory regulation or exceeds the permitted use, you will need to obtain permission directly from the copyright holder. 